\title{
Adherence of intraneural ganglia of the upper extremity to the principles of the unifying articular (synovial) theory
}

\author{
Huan Wang, M.D., ${ }^{1,2}$ Robert Q. Terrill, M.D., ${ }^{3}$ Shota Tanaka, M.D., 1 \\ Kimberly K. Amrami, M.D., ${ }^{1,4}$ Robert J. Spinner, M.D., \\ Departments of ${ }^{1}$ Neurologic Surgery, ${ }^{4}$ Radiology, and ${ }^{5}$ Orthopedics, Mayo Clinic, Rochester, Minnesota; \\ ${ }^{3}$ Worcester Shoulder and Hand Center, and University of Massachusetts Medical School Department of Or- \\ thopedics, Worcester, Massachusetts; and ${ }^{2}$ Department of Hand Surgery, Huashan Hospital, Fudan Univer- \\ sity Shanghai, People's Republic of China
}

\begin{abstract}
Object. Intraneural ganglia are nonneoplastic mucinous cysts contained within the epineurium of peripheral nerves. Their pathogenesis has been controversial. Historically, the majority of authors have favored de novo formation (degenerative theory). Because of their rarity, intraneural ganglia affecting the upper limb have been misunderstood. This study was designed to critically analyze the literature and to test the hypothesis that intraneural ganglia of the upper limb act analogously to those in the lower limb, being derived from an articular source (synovial theory).

Methods. Two patients with digital intraneural cysts were included in the study. An extensive literature review of intraneural ganglia of the upper limb was undertaken to provide the historical basis for the study.

Results. In both cases, the digital intraneural ganglia were demonstrated to have joint connections; the one patient in whom an articular branch was not appreciated initially had evidence on postoperative MR images of persistence of intraneural cyst after simple decompression was performed. Eighty-six cases of intraneural lesions were identified in varied locations of the upper limb: the most common sites were the ulnar nerve at the elbow and wrist, occurring 38 and 22 times, respectively. Joint connections were present in only $20 \%$ of the cases published by other groups.

Conclusions. The authors believe that the fundamental principles of the unifying articular (synovial) theory (that is, articular branch connections, cyst fluid following a path of least resistance, and the role of pressure fluxes) previously described to explain intraneural ganglia in the lower limb apply to those cases in the upper limb. In their opinion, the joint connection is often not identified because of the cysts' rarity, radiologists' and surgeons' inexperience, and the difficulty visualizing and demonstrating it because of the small size of the cysts. Furthermore, they believe that recurrence (subclinical or clinical) is not only underreported but also predictable after simple decompression that fails to address the articular branch. In contrast, intraneural recurrence can be eliminated with disconnection of the articular branch. (DOI: 10.3171/FOC.2009.26.2.E10)
\end{abstract}

KEY WORDS - articular (synovial) theory $\quad$ intraneural cyst $\quad$ intraneural ganglion

I NTRANEURAL ganglia are nonneoplastic mucinous cysts that are found within the epineurium of peripheral nerves. Of the approximately 350 cases in the literature, the vast majority affect the peroneal nerve. For 2 centuries these cysts have been considered curiosities. Their pathogenesis has been controversial and obscure. Recent evidence involving the peroneal nerve at the fibular neck region has demonstrated the lesion's consistent origin from the superior tibiofibular joint and stereotypical appearance. The peroneal intraneural ganglion has served as the prototype for a unifying articular (synovial) theory. ${ }^{87}$

Intraneural cysts in the upper limb are rare, incompletely described, and poorly understood. Joint connections have only seldom been identified in these cases. These features differ markedly from those of extraneural

Abbreviations used in this paper: FSE = fast spin echo; IP = interphalangeal. cysts which are common in clinical practice and in the literature and are well-known and understood by surgeons to be derived from synovial surfaces. Critical analysis and reinterpretation of the available literature on intraneural cysts in this rare location with a modern perspective has not been published previously. The purpose of this paper is to support the notion that joint connections are indeed present in all of these cases; to demonstrate that the principles of the unifying theory that have been previously identified for intraneural ganglia in the lower limb hold true in the upper limb; and to highlight the shared pathogenesis of intraneural and extraneural cysts.

\section{Methods}

This study was initiated by the senior author (R.J.S.) to test a hypothesis without any first-hand experience with this rare location of intraneural cyst. To illustrate the 


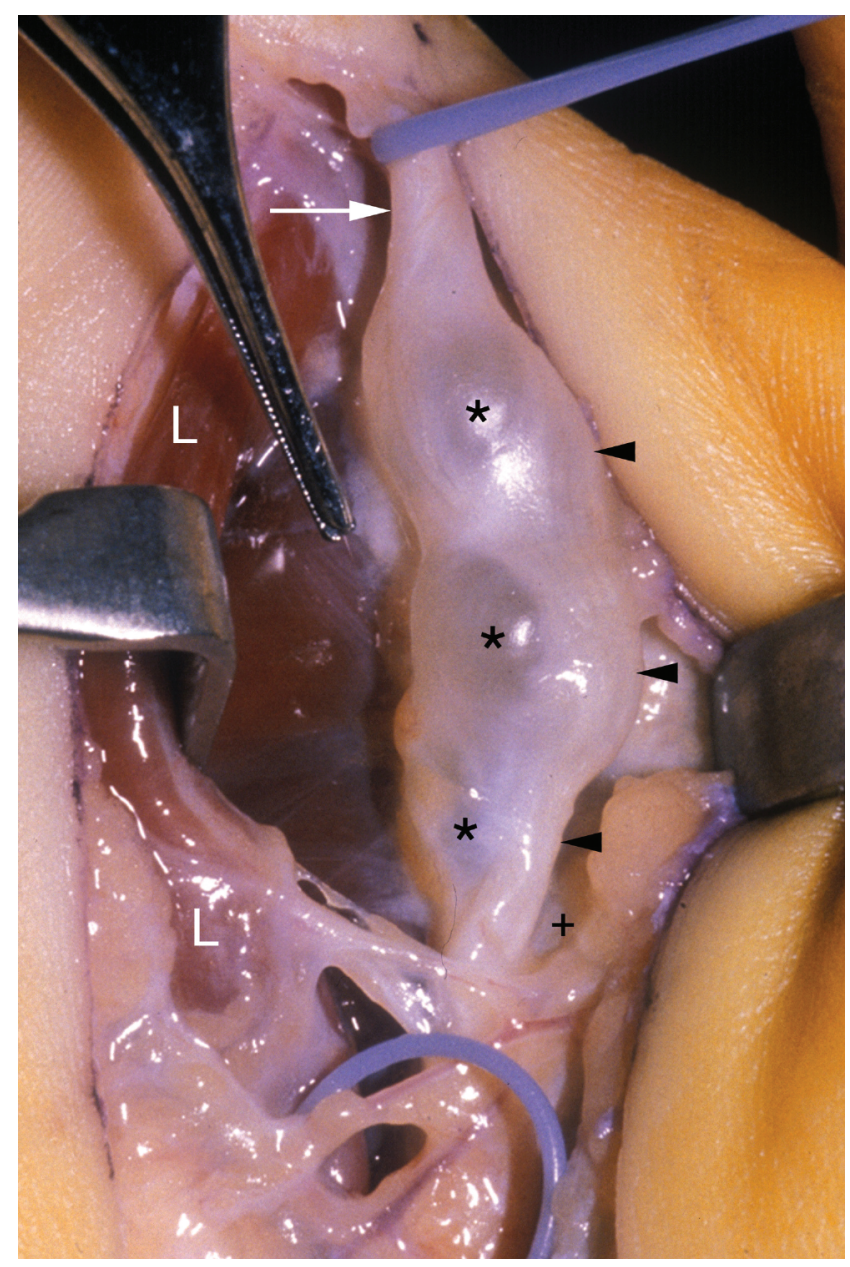

FIG. 1. Case 1. Operative appearance of an intraneural cyst of the radial proper digital nerve to the index finger (arrow). The intraneural ganglion (asterisks) is seen displacing the digital nerve fascicles (arrowheads). The tenting of the cyst toward sensory nerves to the thumb is also vaguely seen (plus sign). $\mathrm{L}=$ lumbrical muscle.

entity, we included 2 cases of intraneural ganglia occurring in a rare site in the upper limb. We then undertook a thorough review of the world literature on intraneural ganglia and intraneural cysts as a whole to identify intraneural ganglion cysts reported in the nerves of the upper extremity. Standard Internet data bases (MEDLINE, searched via PubMed, and Scopus) and Web search engines (Google and Yahoo) were used. All references of retrieved papers were cross-checked. Magnetic resonance images, when available, were analyzed by a musculoskeletal radiologist with experience with intraneural ganglia.

\section{Illustrative Cases}

\section{Case 1}

This 31-year-old woman, who had minor trauma to the volar side of her right dominant hand from weightlifting, immediately developed pain and tenderness along the index finger. Within a few days the pain resolved and numbness developed in the radial aspect of the index finger and a string-like mass was noted longitudinally along the course of its radial digital nerve. Three months after the onset of symptoms, the digital nerve was palpable where it crossed over the metacarpal head. A Tinel sign was elicited along the radial digital nerve starting from the midpalm. Two-point discrimination in the radial digital nerve distribution of the index finger was $>10 \mathrm{~mm}$. An MR imaging study revealed an elongated cystic tubular abnormality in the volar radial aspect of the hand extending from the distal portion of the carpal tunnel to the level of the second metacarpal head. It measured 5-8 $\mathrm{mm}$ in diameter and $5 \mathrm{~cm}$ in length. No joint connection was identified prospectively. The MR images were not available for our review.

Five months after symptom onset the patient was evaluated at our institution. The mass had decreased in size. The radial digital nerve of the index finger was still palpable at the metacarpophalangeal joint level. There was a vague but deep soft tissue mass deep to the thenar muscle and tender to palpation. A Tinel sign was evident at the site of the mass and distally along the radial digital nerve. Two-point discrimination in the distribution of the nerve was $3 \mathrm{~mm}$.

Over the next 3 months, the mass enlarged again and paresthesias developed in the dorsoradial aspect of the index finger. Surgical exploration was performed at the time of this visit. An intraneural ganglion cyst was seen coursing within the radial proper digital nerve to the index finger. Proximally the intraneural cyst was noted within the median nerve just at the take-off of the proper digital nerve. The mass also appeared to involve the takeoff of the sensory nerves to the thumb, just tenting these structures (Fig. 1). Excision of the ganglion cyst with preservation of the nerve and identification and excision of the stalk to the second carpometacarpal joint were carried out.

Postoperatively, the patient experienced some neurogenic pain, which gradually resolved. There was still some hypersensitivity at the radial side of the index finger at 2 months postoperatively, and she regained good use of the hand.

\section{Case 2}

This 51-year-old woman noted the spontaneous onset of numbness and a mass on the dorsoulnar aspect of the right thumb for 3 months. The mass increased and decreased in size, just proximal to the metacarpophalangeal joint of the thumb. The mass transilluminated and was felt to be an extraneural ganglion cyst beneath the dorsal ulnar sensory nerve to the thumb. At operation, a ganglion cyst was noted within the dorsoulnar digital nerve (Fig. 2). It was approximately $5 \mathrm{~cm}$ in length and was larger proximally. It extended distally beyond the level of the IP joint. The cyst was decompressed. No specific joint connection was noted. Postoperatively the numbness improved. While there was no clinical recurrence of swelling within the nerve, a sizable mucous cyst developed from the IP joint of the thumb and subsequently largely disappeared. A postoperative MR imaging study performed 4 months later demonstrated persistence of a small remnant of intraneural cyst and the development of the extraneural cyst, both connected to the IP joint (Fig. 3). 


\section{Upper extremity intraneural ganglia}

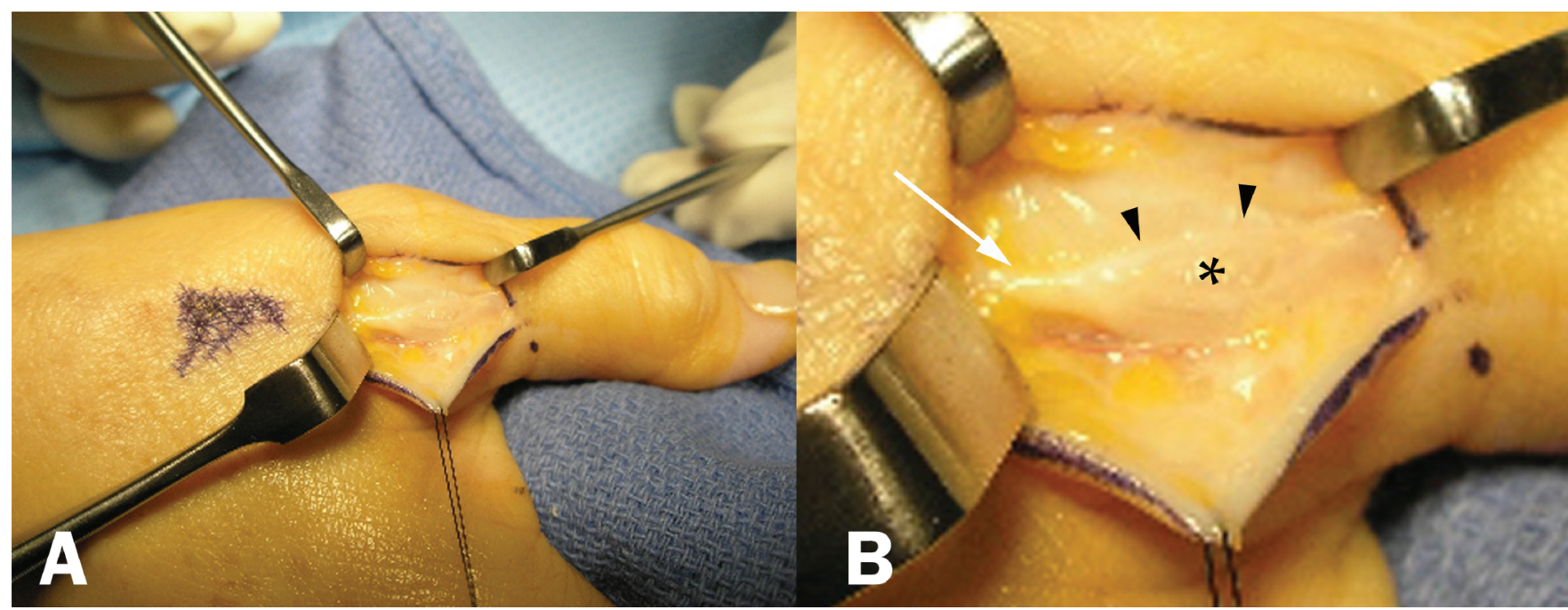

FIG. 2. Case 2. Operative findings of a ganglion cyst in the dorsoulnar digital nerve of the thumb. A: Initially, a limited dorsal exposure over the metacarpophalangeal joint of the right thumb revealed an intraneural ganglion cyst within the dorsoulnar digital nerve. The exposure was subsequently lengthened distally (not illustrated). B: Close-up view of A. The dorsoulnar digital nerve (arrow) had cystic enlargement within it (asterisk). Nerve fascicles (arrowheads) were displaced eccentrically.

The patient also had a history of a recurrent extraneural ganglion on the volar ulnar aspect of the left wrist that arose from the distal radioulnar joint. Four years ago, the mass was resected again and the joint opening was oversewn with good results.

\section{Results}

We identified a total of 86 cases (involving 87 nerves) of intraneural ganglia affecting nerves of the upper limb described in 65 reports. One case that was published in 2 articles was recorded one time. ${ }^{63,94}$ For the purposes of this study, we considered the Zum Busch article ${ }^{100}$ as the earliest case in the upper limb as this is widely cited as such. (Note that earlier cases can be substantiated; ${ }^{88}$ see Discussion.) These cases were reported in the following languages: English (26), Japanese (25), German (8), Italian (3), French (2), and Korean (1). Of these cases only 56 (35 reports) were listed in PubMed. We excluded published cases in the following 3 categories: 1) cases affecting the axial cervical spine, including one case of a hypoglossal cyst presumably derived from the atlantooccipital joint ${ }^{6,82}$ that we believe was extraneural (see third exclusion criterion below); 2) cases reported in the 19th and early 20th century and described as "blood cysts," myxomas (fibromyxomas, myxofibromas), and cystic benign or malignant nerve sheath tumors (including "gliomas"); and 3) cases described in a manner that did not allow us to distinguish adequately between intraneural or extraneural ganglia or to substantiate the intraneural nature of the cyst.

Intraneural gangliawere identified in the following sites: suprascapular in the shoulder (6): ${ }^{58,67,69,76}$ ulnar (38 at the elbow $^{2,3,10,14,15,17,24,29,32,34-38,40,42-44,47-50,57,60-63,65,67,68,70,73,91-94,98,100}$ and 22 at the wrist $\left.^{2,3,11,15,19,25,26,28,41,45,54-56,64,67,72,89,90,99}\right)$; median (3 at the elbow ${ }^{3,4,31}$ and 3 at the wrist $\left.{ }^{39,66,67}\right)$; radial $(1)^{41}$ and posterior interosseous at the elbow (1); ${ }^{33}$ superficial radial (3), ${ }^{13,16,27}$ lateral antebrachial cutaneous (1), ${ }^{66}$ dorsal cutaneous branch of the ulnar (3), ${ }^{21,26,66}$ posterior antebra- chial cutaneous of the radial (1) $)^{53}$ and palmar cutaneous branch of the median (1) ${ }^{19}$ at the wrist; and digital nerves $(4)^{26}$ in the hand. One patient had 2 digital cysts involving the "radial collateral" and "dorsal collateral" nerves near the metacarpophalangeal joint of the thumb. ${ }^{26}$ Nineteen of those cysts were found to be connected to the joints: suprascapular nerve and the glenohumeral joint (3); ${ }^{67,76}$ median nerve and the trapeziometacarpal joint $(1)^{67}$ and the radiocarpal joint (1);39 ulnar nerve and the humeroulnar joint (11); $; 4,37,38,48,60-63,67,92,94$ and the ulnar nerve to the distal radioulnar joint $(1)^{67}$ and its deep branch to the carpometacarpal joint (2). ${ }^{11,99}$ The remaining cysts, not identified as being joint-related, were all paraarticular.

Of the 86 reported cases included in this study, patient demographic information was only available in 76 . The patients in these 76 cases were 61 men and 15 women. Their age ranged from 12 to 72 years, with an average of 46.8 years. Within this group, there were 14 cases in which the authors reported that MR images had been obtained $^{10,17,24,26,33,39,45,58,63,66,69,76,94,98}$ and 11 had published images available. ${ }^{10,17,24,26,33,45,58,63,76,94,98}$ In the majority of cases, the suboptimal resolution and limited number of published images did not allow us to glean much useful information from the MR images. In one case,${ }^{10}$ the most recent one, which involved an ulnar intraneural ganglion occurring near the elbow, published MR images allowed us to identify a previously unrecognized elbow joint connection (Fig. 4). In another case, which involved the posterior interosseous nerve, ${ }^{33}$ the joint connection to the elbow joint at the lateral aspect of the radial head could be appreciated in 2 planes on the published MR images.

\section{Discussion}

We have collected and analyzed a relatively large number of cases of upper limb intraneural ganglia to make some generalizations and specific comments regarding the pathogenesis of a rare entity occurring in rare loca- 

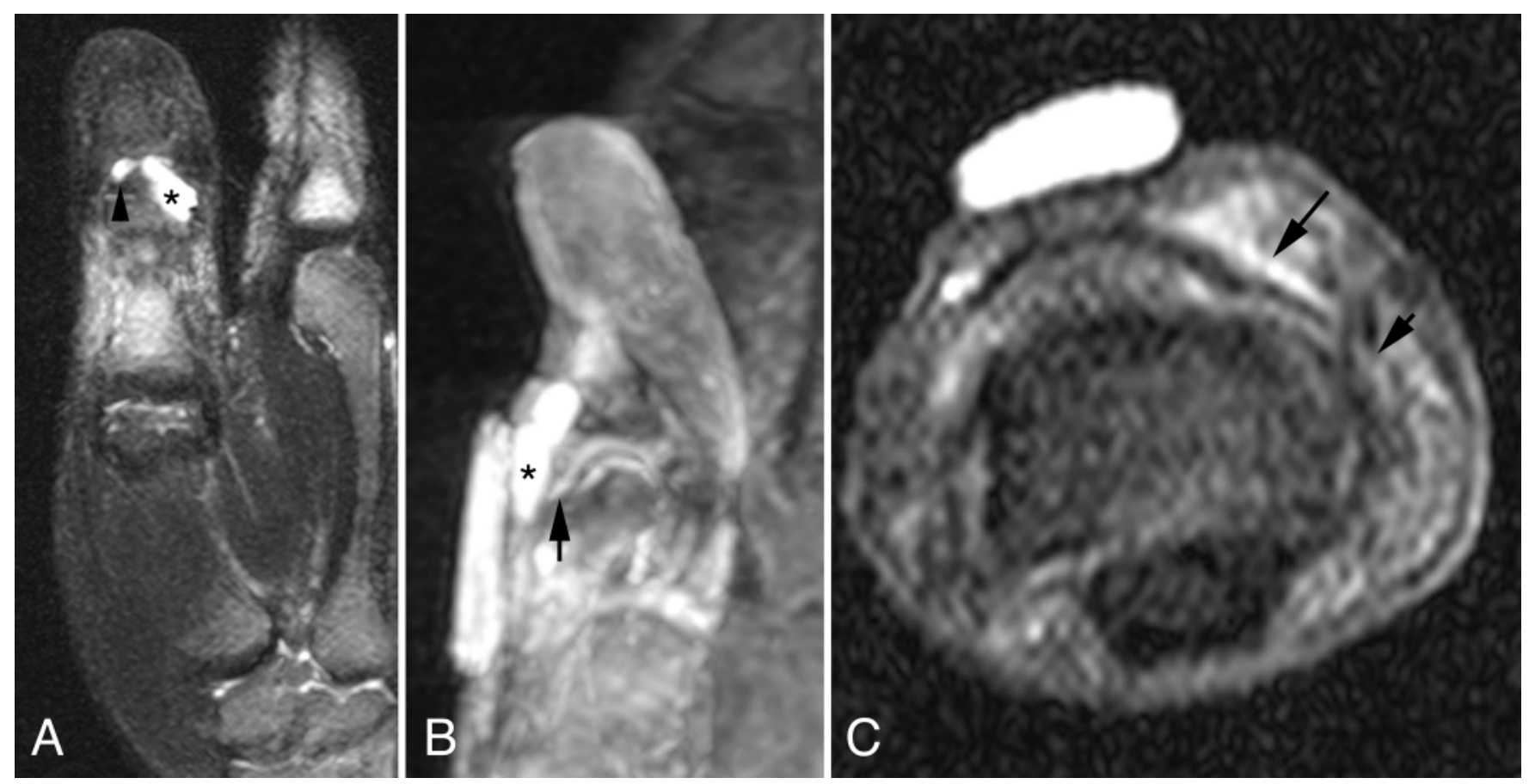

FIG. 3. Case 2. Magnetic resonance images demonstrating the predicted postoperative intraneural recurrence. A: Coronal maximum intensity projection from a fat-saturated T2-weighted FSE image set shows the intraneural cyst involving the ulnar digital nerve (asterisk). In addition, extraneural extension to the radial side of the thumb at the level of the IP joint is evident (arrowhead). B: Sagittal maximum intensity projection from a fat-saturated T2-weighted FSE image set shows the intraneural cyst (asterisk) at the dorsal aspect of the ulnar thumb. The connection to the IP joint is seen on this image (arrow). Note cyst extension distal to the joint of origin. C: Axial T2-weighted FSE image with fat suppression at the level of the IP joint of the thumb shows the connection to the IP joint through the articular branch (long arrow) and cyst within the digital nerve (short arrow).

tions. Based on our interpretation of the cases included in this paper, we believe that the unifying articular (synovial) theory applies to these cases of intraneural ganglia in the upper limb and that the joint-related connection often goes unrecognized leading to the historical misconception of de novo formation (degenerative theory).

\section{Unifying Theory}

In 2003, we proposed a unifying (synovial) theory based on the peroneal nerve at the fibular neck and its connection to the anterior portion of the superior tibiofibular joint.$^{80,81}$ We believe that capsular rents may lead to dissection of joint fluid into and along an articular branch leading to intraneural ganglia or into the neighboring tissues (apart from the articular branch) leading to extraneural ganglia. For intraneural ganglia at this site, we have demonstrated a stereotypical appearance that follows anatomical and hydrodynamic principles. Extraneural ganglia may arise from sources of synovium (joints, bursae, tendon sheaths, and so forth). Most commonly, these extraneural cysts present on the dorsal wrist and originate from the scapholunate joint through a nonneural "pedicle." In our opinion, extraneural cysts do not invade epineurium and become intraneural in nature. Extraneural cysts can compress or adhere to nerve and be mistaken for intraneural cysts.

In the past few years, this theory has been tested and substantiated at other unusual sites in the lower limb by our group ${ }^{8,9,86}$ and others. ${ }^{7,20,51,52,67}$ Experience has allowed us to elaborate upon 3 fundamental principles for the formation and propagation of intraneural ganglia in the lower limb ${ }^{79}$ which we believe are applicable to those cases in the upper limb.

\section{Fundamental Principles}

Joint Connections. Joint connections were identified by the original authors in only $22.1 \%$ of these cases (19 of 86$)-20.2 \%$ (17 of 84) if we exclude the suprascapular nerve cases previously published by our group. ${ }^{76}$ (Note: illustrated cases were also not included.) In this review, all of these cases of upper limb intraneural ganglia were paraarticular and were derived from appendicular joints in the region. (Note: Information was typically insufficient to determine the specific wrist joint connection.) We have previously shown that even the sporadic intraneural ganglia described as remote from a joint, still have an unrecognized joint origin. ${ }^{46,86}$ Joint connections may be small, easily missed, and not imaged or explored, and cysts may still enlarge far from joints: $;^{1,96}$ these connections have not been identified routinely because of the cyst's rarity and radiologists' and surgeons' unfamiliarity and inexperience with them. ${ }^{75}$ In many early cases there were no highresolution MR imaging scans, such as can be performed with current imaging equipment, techniques, and parameters. All of these nerves affected with ganglia have de- 


\section{Upper extremity intraneural ganglia}
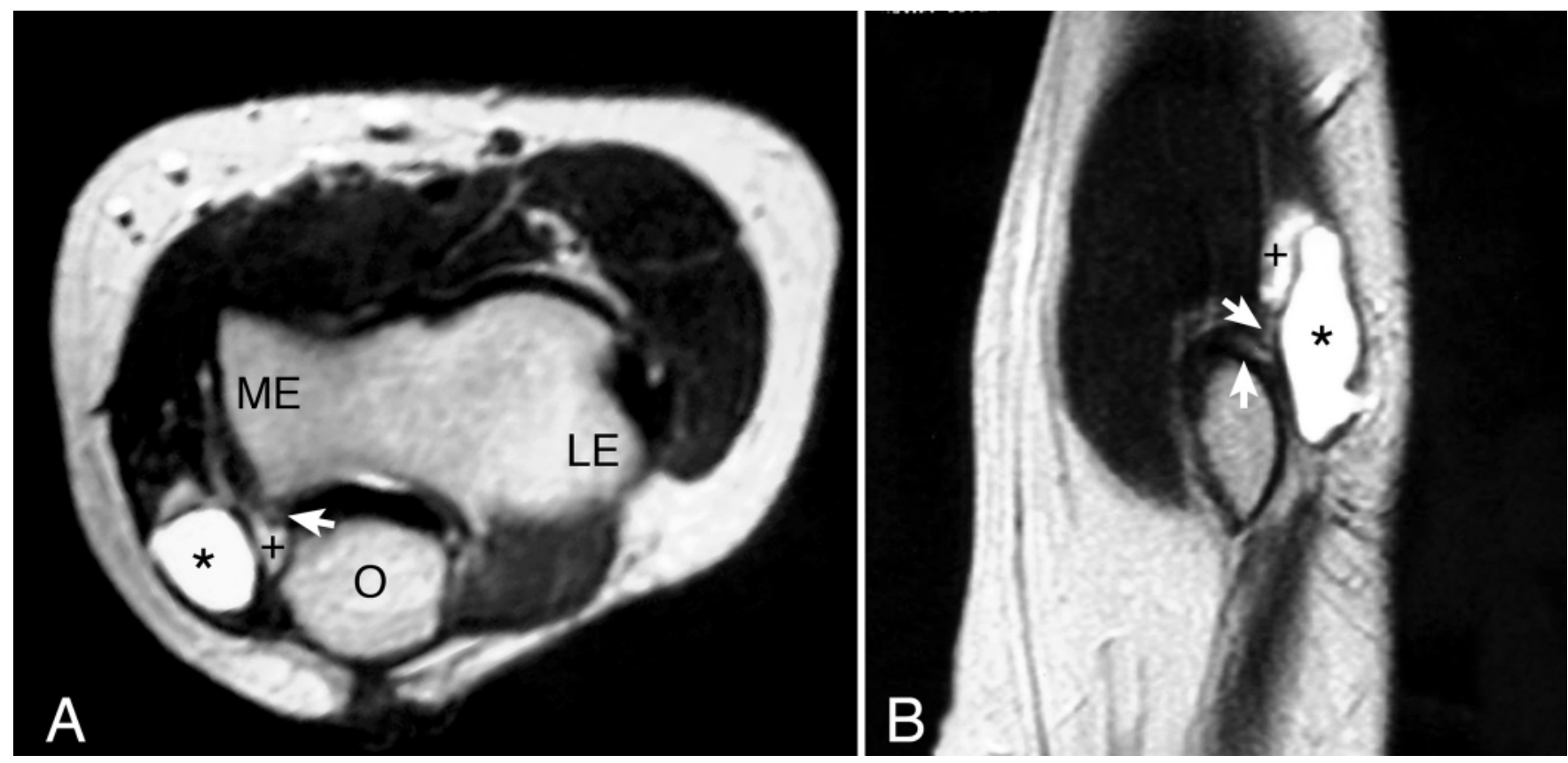

FIG. 4. Previously published case of an ulnar intraneural ganglion cyst with an unrecognized joint connection. A: Axial T2weighted image at the level of the distal humerus demonstrates the intraneural cyst within the ulnar nerve within the cubital tunnel (asterisk). Note displacement of the nerve fascicles around the cyst, the "signet ring" sign. The connection of the cyst (plus sign) to the elbow joint is seen on this image (arrow). $\mathrm{ME}=$ medial epicondyle; $\mathrm{LE}=$ lateral epicondyle; $\mathrm{O}=0$ olecranon. B. Sagittal T2-weighted FSE image showing the longitudinal extent of the cyst (asterisk) and the connection of the cyst (plus sign) to the posterior elbow joint (arrows). Modified from Boursinos et al.: Hand 2:12-15, 2007.

scribed articular branches ${ }^{71}$ to the joints. Interestingly, in all examples of upper limb intraneural ganglia there was at least 1 case of a joint connection identified at each of the most commonly affected nerves/sites.

Our belief is bolstered by considering certain additional information. We have demonstrated this consistent finding with imaging and with operation in the lower limb. ${ }^{79-81,85-87}$ We have also shown this in 4 cases of intraneural ganglia at 2 rare sites in the upper limb. In 3 cases the joint connections were not identified initially; the cases presented to us sequentially were shown at reinterpretation or at follow-up examination to have joint connections (in Case 1 in this paper and in 2 cases of suprascapular intraneural ganglia that we reported in a previous $\left.\operatorname{article}^{76}\right)$. We were able to identify previously unrecognized joint connections in 2 cases (ulnar ${ }^{10}$ and posterior interosseous $\mathrm{s}^{33}$ intraneural ganglia) in which appropriate images were published that could allow us to reinterpret films and identify a joint connection. Two historic cases reported before prior knowledge or imaging of theories on joint connections represent robust evidence to support a joint connection: 1) the earliest known case of an intraneural cyst (1810) located within the ulnar nerve, originally thought to be a serous cyst, has recently been reinterpreted as an elbow joint-related ganglion; ${ }^{12,88}$ and 2) a cadaveric specimen listed in a catalog $(1929)^{4}$ of a cyst within the deep branch of the ulnar nerve connected to one of the carpal joints. One other case is particularly revealing: ironically, Jenkins ${ }^{41}$ who, like Cutler and Gross, ${ }^{18}$ believed that intraneural ganglia were derived from degeneration of cystic nerve sheath tumors, described one case in which it was necessary to "excise the pisiform to obtain access to the deepest part (of the cyst)"; to us, he is describing an articular connection to the wrist.

Certain data are especially informative regarding the underlying mechanism of the pathogenesis of these cysts. The strong association of degenerative joint disease and intraarticular pathology seen in the lower limb cases is also reflected in these upper limb cases. Trauma was identified in 19 (25\%) of 76 cases in which enough clinical information was reported. Nineteen (50\%) of 38 ulnar nerve cases at the elbow had dysplastic or degenerative findings. Labral tears were demonstrated in 2 cases of suprascapular nerve ganglia. Arthrography performed in 2 cases demonstrated communications of the joint with the cyst through a capsular tear. ${ }^{34,76}$ Still, we recognize that even with arthrography, delayed arthrography or exercise might be necessary to reveal the joint communication with the cyst (as is the case with extraneural cases). ${ }^{51,77}$ Furthermore two of the cases confirmed neural tissue histologically within the "pedicle/stalk" of the articular branch. ${ }^{34,60}$

Occam's razor would favor a shared pathogenesis of the unifying articular (synovial) theory-not only of intraneural ganglia in the upper limb following a mechanism similar to that of those in the lower limb, but also of intraneural ganglia following a mechanism similar to that of extraneural ganglia. This theory seems far more logical than other theories on the subject, especially the degenerative one. ${ }^{87}$

Path of Least Resistance. Intraneural propagation within the epineurium occurs following the path of least 
resistance. ${ }^{22}$ Just as in the lower extremity where extensive longitudinal dissection of cyst may occur (for example, buttock level extension of a peroneal nerve ${ }^{30,95}$ ) we identified a similar situation where an ulnar nerve cyst propagated from the cubital tunnel to the infraclavicular brachial plexus. ${ }^{17}$ A suprascapular intraneural ganglia arising from the glenohumeral joint extended to the neck. ${ }^{76,78}$

We have also shown that when intraneural cyst extends to a major branch, be it the sciatic nerve for peroneal or tibial nerves in the lower limb, ${ }^{79}$ or the upper trunk for suprascapular nerve, ${ }^{78}$ it can cross over. For example, cyst within a primary neural pathway (such as the peroneal nerve) can fill the tibial nerve (a secondary pathway) after expanding within the sciatic nerve. These patterns of primary and secondary proximal ascent and distal descent are clearly dependent on pressure fluxes.

In the lower limb, we have shown that the preferential pathway often is in a proximal direction with more limited distal descent. ${ }^{83}$ The intraneural cyst typically has characteristic clinical and imaging features: ${ }^{85} \mathrm{a}$ relatively narrowed neck ("tail" sign); a tubular appearance because of its confines within the nerve; a balloon-like expansion ("balloon" sign) wherein fascicles are displaced by cyst ("signet ring" sign); and further evidence of an ascending streak. These features suggest the common effects of intraarticular pressures along a path of least resistance.

The nature of this retrospective review of literature spanning 2 centuries has inherent limitations. Still, it seems clear to us that the initial phase of cyst propagation is "primary ascent" from a synovial joint along the articular branch. ${ }^{83}$ Directionality of further cyst propagation could not be assessed accurately due to the number of cases, paucity of high resolution MR images obtained, and limited operative descriptions. With some documented exceptions, predominant proximal ascent seems to occur but further study is required to confirm this pattern of extension in these rare lesions in the upper extremities. In addition, it is likely that pressures and pressure fluxes give rise to complex patterns of ascent, descent, and cross-over. For cases of ulnar intraneural ganglia at the elbow, different patterns have been described (with joint connections): many within the cubital tunnel; some with proximal extension; ${ }^{2,10,17,32,34,62,93,98}$ others with distal extension; ${ }^{38,63,92,94}$ and others perhaps with combinations of proximal and distal extension. ${ }^{35,43,65}$ Possible explanations for the apparent exaggerated distal descent (that is, other patterns) include: 1) increased pressures (for example, from scar tissue) causing the path of least resistance to be distal; 2) inaccurate representation (misunderstanding or misrepresentation) of pathology; and 3) misdiagnosis of an extraneural rather than intraneural cyst (these may appear similar). We suspect that scarring from previous surgery can lead to exacerbation of other pathways and distal descent. We demonstrated this in a sural intraneural case. ${ }^{9}$ Initially predominant ascent occurred. At operation the articular trunk was ligated but not at the level of the subtalar joint of origin. Surgical ligation of a nerve led to increased resistance. Follow-up MR imaging revealed prominent descent down a remaining neural pathway. Furthermore, the extrinsic pressures of locations such as the carpal tunnel and cubital tunnel are likely to play a role in determining cyst size, shape, and dimensions that is not fully appreciated; patterns underlying these pressures need to be defined.

In addition, depending on the site of the capsular rent, the path of least resistance can occur within nerve and/or outside of nerve leading to intraneural and/or extraneural cyst. This combination of different types of cysts has been seen in the lower limb and was represented in cases in the upper limb ${ }^{25}$ as well as in Case 2 in the present paper. Intraneural and extraneural cysts can coexist or occur sequentially ${ }^{48}$ Other cases of less common, more complex (adventitial) ganglia also may present similarly. ${ }^{23,97}$

The one case in which 2 separate digital intraneural cysts were reported ${ }^{26}$ may well represent simultaneous intraneural cyst development along 2 different nerves from a single joint ${ }^{84}$ Another possibility for 2 different intraneural nerves would be the cross-over phenomenon. ${ }^{79}$

Finally, 2 cases ${ }^{5,59}$ interpreted as intraneural ganglia were excluded from our data analysis based on their MR images. Limited MR images available for review suggested that the lesions were extraneural ganglia without close proximity to a nerve with their joint connections to the shoulder joint probably unrecognized at the time of initial imaging and subsequent surgery.

Pressure and Pressure Fluxes. Pressure fluxes, presumably related to increased intraarticular pressures (such as in strenuous activity), have been described in lower limb intraneural cysts as responsible for intermittent symptoms and fluctuating findings on examination and imaging. Similarly, several cases of fluctuating symptoms and cyst size occur in the upper limb $b^{64,66}$ (for example, in our 2 illustrative cases). The abrupt nature of the decrement in the cyst size suggested that cyst rupture (along with resorption) can result in pressure fluxes in certain cases. The intermittent, episodic nature of the symptoms and fluctuating cyst size is well known to hand surgeons from their experience with the common simple extraneural ganglia. Pressure and pressure fluxes without doubt lead to more extensive extension of cysts along the path of least resistance as described above.

\section{Implications of This Study}

Potentially, any articular branch to a synovial joint can be affected by an intraneural ganglion. We believe that the number of cases is underestimated; many isolated cases are unreported; and at least some of the early cases of intraneural cysts with limited descriptions and different pathologic diagnoses likely represent intraneural ganglia. We also suspect that other cases of intraneural ganglia may go unrecognized and be causes of pain syndromes, such as those involving the posterior interosseous nerve at the wrist.

The purpose of this study is not to establish treatment guidelines or to be definitive about the elimination of recurrences. Based on our experience with these ganglia, we believe that cyst decompression should be performed along with disconnection of the articular branch. Intraneural recurrence can be eliminated when the articular branch is disconnected at or near the joint of origin..$^{76,80,81,86,87} \mathrm{We}$ 
believe that resection of the entire cyst and its wall is unnecessary; this only results in unnecessary intraneural dissection and risk of neural injury. The joint seems to be the root of the pathology and wherever possible the reversal of intraarticular pathology would seem to be the most direct means of correcting the problem. Although we have recommended resection of the superior tibiofibular joint (synovium) in cases of peroneal or tibial intraneural ganglia arising from this joint, resection of other joints should not be performed. We anticipate that arthroscopic methods to treat these connections can be designed in the future. We anticipate that a joint-derived procedure could potentially address all of the pathology.

While recurrences for lower limb intraneural ganglia have been reported to be as high as $30 \%$ when simple decompression was done without disconnection of the articular branch, they were not described in any of these cases. In many cases follow-up information was unavailable, and postoperative MR imaging studies were rarely performed. We are aware of one case that became apparent after publication. ${ }^{66}$ In certain instances we predicted intraneural persistences/recurrences and then demonstrated examples (in illustrated Case 2 of the digital nerve in this paper and the suprascapular nerve case previously reported $^{76}$ ). We believe that this incidence of symptomatic or subclinical recurrences is underestimated and that long-term follow-up and postoperative MR imaging is necessary for accurate surveillance. In our opinion there is a logical explanation for the apparent lower recurrence rate noted in this review. In many of these cases in the upper limb, especially where mobilization of proximal and distal "normal" nerve is obtained (for example, when the ulnar nerve is transposed at the elbow), the articular branch may be unknowingly disconnected. Extraneural recurrences which in our experience are often subclinical can still occur and are reflective of the pathologic degenerative joint.

\section{Conclusions}

Previous research on the prototype peroneal intraneural ganglia set the stage for the unifying articular (synovial) theory. This theory, which has been tested at other nerves and sites in the lower limb, can now be generalized to both common and rare sites of intraneural ganglia in the upper limb. With further experience with these cysts, predictable patterns of cyst propagation will be appreciated in these lesions, much as they have been in those in the lower limb. As with lower limb intraneural ganglia careful attention to image acquisition and interpretation of images and intraoperative pathology is required to prospectively identify joint connections and true extent of the intraneural cysts in the upper limb. ${ }^{74}$

\section{Acknowledgments}

The authors appreciate the intellectual encouragement of James H. Dobyns, M.D. and Michael B. Wood, M.D.; the translations skills of Nobuyuki Yamamoto, M.D. (Rochester, Minnesota); and the willingness of Mukund R. Patel, M.D. (Brooklyn, New York) as well as Loukas A. Boursinos, M.D., and Christos G. Dimitriou, M.D., (Thessaloniki, Greece) to share clinical information with us.

\section{Disclaimer}

The authors report no conflict of interest concerning the materials or methods used in this study or the findings specified in this paper.

\section{References}

There are numerous Japanese articles in the reference list and one article in Korean. These articles do not have equivalent English titles or journal names. The authors had all these original articles translated and wish to include these important papers in the reference list so that other researchers may readily identify these sources in the future.

1. Adolfsson L: Ganglion cyst communicating with the elbow joint presenting as a distal forearm tumour. J Hand Surg 22B: 552-554, 1997

2. Allieu Y, Cenac PE: Peripheral nerve mucoid degeneration of the upper extremity. J Hand Surg 14A: 189-194, 1989

3. Allieu Y, Dersarkissian Y, Teissier J, Kassab A: Neuf cas de dégénérescence mucoïde des nerfs. Complication d'un syndrome canalaire? Rev Chir Orthop 73 (11 suppl):243-248, 1987

4. Anonymous: A Descriptive Catalogue of the Pathological Museum of St. Bartholomew's Hospital Medical College. Published by Order of the College Council. London: Adlard \& Son, 1929, Vol 2, pp 1269

5. Arnold PM, Oldershaw JB, McDonald LW, Langer BG: Myxomatous cyst of the brachial plexus. J Neurosurg 73: 782-784, 1990

6. Baldauf J, Junghans D, Schroeder HW: Endoscope-assisted microsurgical resection of an intraneural ganglion cyst of the hypoglossal nerve. J Neurosurg 103:920-922, 2005

7. Bäzner UM, Richter HP, Antoniadis G: Intraneural ganglia-diagnosis and treatment options for this rare nerve lesion, in the $5^{\text {th }}$ Annual meeting of the German Society of Neurosurgery (DGNC). Würzburg, Germany: Italian Neurosurgical Society (SINch), 2008

8. Blitz NM, Amrami KK, Spinner RJ: Magnetic resonance imaging of a deep peroneal intraneural ganglion cyst originating from the second metatarsophalangeal joint. A pattern of propagation supporting the unified articular (synovial) theory for the formation of intraneural ganglia. J Foot Ankle Surg [in press]. 2009

9. Blitz NM, Prestridge J, Amrami KK, Spinner RJ: Posttraumatic, joint-connected sural intraneural ganglion with a new pattern of intraneural recurrence. J Foot Ankle Surg 47:199205, 2008

10. Boursinos LA, Dimitriou CG: Ulnar nerve compression in the cubital tunnel by an epineural ganglion: a case report. Hand 2:12-15, 2007

11. Bowers WH, Doppelt SH: Compression of the deep branch of the ulnar nerve by an intraneural cyst. Case report. J Bone Joint Surg (Am) 61:612-613, 1979

12. Bulletin de la Faculté de Médecine de Paris, et de la Société établié dans son sein. Tome second, n 3 (Cote BIUM: 90089), 1810

13. Campailla E: [On so-called cystic degeneration of peripheral nerve trunks.] G Psichiatr Neuropatol 95:967-76, 1967 (Italian)

14. Chan KM, Thompson S, Amirjani N, Satkunam L, Strohschein FJ, Lobay GLW. Compression of the ulnar nerve at the elbow by an intraneural ganglion: J Clin Neurosci 10:245-248, 2003

15. Chick G, Alnot JY, Silbermann-Hoffman O: Intraneural mucoid pseudocysts. A report of ten cases. J Bone Joint Surg (Br) 83:1020-1022, 2001

16. Chodkow WN: Ganglien der peripherischen Nerven. Zentralbl Chir 53:680, 1926

17. Choi SH, Kim CH, Kim MO, Jung HY: [Intraneural ganglion 
of the ulnar nerve. A case report.] J Korean Assoc EMGElectrodiagn Med 1:222-225, 1999 (Korean)

18. Cutler EC, Gross RE: The surgical treatment of tumors of the peripheral nerves. Ann Surg 104:436-452, 1936

19. De Santis G, Villani M, Pederzini L, De Luca D, Soragni O, Luchetti R: Su due casi di pseudocisti mucoidi nervi periferici. Chir Org Mov 71:159-163, 1986

20. De Schrijver F, Simon JP, De Smet L, et al: Ganglia of the superior tibiofibular joint: report of three cases and review of the literature. Acta Orthop Belg 64:233-241, 1998

21. Dubs J: Ganglion der Nervenscheide des N. ulnaris. Dtsch Med Wochenschrift 48:68, 1922

22. Elangovan S, Odegard GM, Morrow DA, Wang H, Hébert-B1ouin MN, Spinner RJ: Intraneural ganglia: A clinical problem deserving a mechanistic explanation and model. Neurosurg Focus 26(2) E11, 2009

23. Falcone MO, Benoit $\mathrm{O}$, Dasnoy D, Strouk G, Polvèche G: [Adventitial mucoid cyst of the radial artery associated with volar wrist ganglion. A case report.] Chir Main 26:120-123, 2007 (Fr)

24. Ferlic DC, Ries MD: Epineural ganglion of the ulnar nerve at the elbow. J Hand Surg (Am) 15:996-998, 1990

25. Foucher G, Berard V, Snider G, Lenoble E, Constantinesco A: Distal ulnar nerve entrapment due to tumors of Guyon's canal. A series of ten cases. Handchir Mikrochir Plast Chir 25:61-65, 1993

26. Giele H, Le Viet D: Intraneural mucoid cysts of the upper limb. J Hand Surg (Br) 22:805-809, 1997

27. Gillies RM, Burrows C: Nerve sheath ganglion of the superficial radial nerve. J Hand Surg (Br) 16:94-95, 1991

28. Gurdjian ES, Larsen RD, Lindner DW: Intraneural cyst of the peroneal and ulnar nerves. Report of two cases. J Neurosurg 23:76-78, 1965

29. Hansis M, Reill P, Meeder PJ: [Intraneural ganglion of the ulnar nerve. A case report.] Unfallchirurg 91:405-407, 1988 (Ger)

30. Harbaugh KS, Tiel RL, Kline DG: Ganglion cyst involvement of peripheral nerves. J Neurosurg 87:403-408, 1997

31. Hartwell AS: Cystic tumor of median nerve; operation: restoration of function. Boston Med Surg J 144:582-583, 1901

32. Harway RA: Ulnar neuropathy due to intraneural cyst. Orthopedics 20:354-355, 1997

33. Hashizume H, Nishida K, Nanba Y, Konishike T: Intraneural ganglion of the posterior interosseous nerve with lateral elbow pain. J Hand Surg (Br) 20B:649-651, 1995

34. Hori S, Surgimura I, Muraoka H, Tatsukawa K, Kuroki H: [Intraneural ganglion of the ulnar nerve. Report of two cases.] Jpn Orthop Surg Traum Surg 35:269-273, 1986 (Jpn)

35. Inhofe PD, Moneim MS: Compression of the ulnar nerve at the elbow by an intraneural cyst: A case report. J Hand Surg (Am) 21:1094-1096, 1996

36. Inoue $\mathrm{H}$ 井上博, 山中健輔, 横田清司, 後藤㻖也, 多平史 郎: 遅発性尺骨神経麻舫とganglion. 整形外科(臨時増刊) 28:1541-1545, 1977

37. Inukai $\mathrm{T}$, Itou $\mathrm{N}$ : [Ulnar nerve palsy due to epineural ganglion: a case report.] Seikei Geka 47:1013-1016, 2004 (Jpn)

38. Irie Z 入江善二, 宮田慶男, 高井秀典, 橋本幸生, 種森孝至, 西川秋佳: 神経内ガングリオンによる尺骨神経麻盘の1例. 高山赤十字病院紀要 8:57-60, 1984

39. Jaradeh S, Sanger JR, Maas EF: Isolated sensory impairment of the thumb due to an intraneural ganglion cyst in the median nerve. J Hand Surg 20B:475-478, 1995

40. Jardini DA: Tumore cistico del nervo cubitale. Arch Ortop 24:139-147, 1907

41. Jenkins SA: Solitary tumors of peripheral nerve trunks. J Bone Joint Surg (Br) 34:401-411, 1952

42. Kaminuma $S$ 神沼誠一, 大井淑雄, 村井俊彦, 伊地知正光, 大 木勲, 塚本創一郎: 尺骨神経に発生したガングリオンの1例. 関東整災誌 6:112-115, 1975
43. Kamori $\mathrm{M}$ 嘉森雅俊, 梅沢健司, 杉浦昌, 斉藤好道, 石黒直 樹, 清水卓也: 左肘部尺骨神経内ガングリオンの1例 臨床整 形外科 20:1337-1339, 1985

44. Kawakita T 川北哲, 手井喜久男, 清水俊治, 三輪茂樹: 神経 内ganglionによる尺骨神経麻瘏の1例. 中部整災誌 27:2285, 1984

45. Kitamura T, Oda Y, Matsuda S, Kubota H, Iwamoto Y: Nerve sheath ganglion of the ulnar nerve. Arch Orthop Trauma Surg 120:108-109, 2000

46. Krishnan KG, Schackert G: Intraneural ganglion cysts: a case of sciatic involvement. Br J Plast Surg 56: 183-186, 2003

47. Kunitomo Y 國友泰輔, 今泉佳宣, 大橋俊郎, 谷知久, 大友克 之, 塚原隆司: 尺骨神経内に生じたガングリオンによる肘部 管症候群の1例. 中部整災誌 43:824,2000

48. Kushida $\mathrm{K}$ 櫛田和義, 高橋定雄, 安藤正, 高見博: 尺骨神経内 ガングリオンの1例. 臨床整形外科 16:900-903, 1981

49. Lohmeyer JA, Kimmig B, Gocht A, Machens HG, Mailander P: Combined manifestation of a neurofibroma and a nerve sheath ganglion in the ulnar nerve after radiotherapy in early childhood. J Plast Reconstr Aesthet Surg 60:1338-1341, 2007

50. Maeda $\mathrm{T}$ 前田敏明, 小林誠, 松井猛, 中土幸男, 秋月明, 斉藤 覚: ガングリオンによる末梢神経麻痺 中部整災誌 27:957959, 1984

51. Malghem J, Vande berg BC, Lebon C, Lecouvet FE, Maldague BE.: Ganglion cysts of the knee: articular communication revealed by delayed arthrography and CT after arthrography. AJR Am J Roentgenol 170:1579-1583, 1998

52. Malghem J, Lecouvet FE, Vande Berg BC, Lebon $\mathrm{CH}$, Maldague BE: Intraneural mucoid pseudocysts: a report of ten cases. J Bone Joint Surg (Br) 85:776-777, 2003

53. Matsuda K 松田和美, 児島忠雄, 河野稔彦: 稀なガングリオ ンの3例. 形成外科 25:153-157, 1982

54. Menge M, Tachibana S: [Intraneural compression of the ulnar nerve by a ganglion.] Handchirurgie 12:15-17, 1980 (Ger)

55. Mohsenipour I, Twerdy K, Grunert V: Intraneurales Ganglion des N. ulnaris. Fallbeschreibung. Zentralbl Neurochir 47:63-65, 1986

56. Müller G, Mikuz G, Scharfetter F: Uber eine intraneurales Ganglion des Nervus ulnaris am Handgelenk. Schweiz Arch Neurol Neurochir Psychiatrie 109:99-105, 1971

57. Murotani K 室谷勝久, 矢形義近, 村尾浩平, 林修, 丹羽智章, 浅野頼子: 尺骨神経内ガングリオンの1例. 整形・災害外科 31:1613-1616, 1988

58. Nagele M, Lienemann A, Hahn D, Witt T: [Intraneuronal ganglia: value of diagnostic radiologic possibilities.] Digitale Bilddiagn 8:14-17, 1988 (Ger)

59. Nakamichi K, Tachibana S: Intraneural ganglion of the brachial plexus. J Hand Surg (Br) 23:123-125, 1998

60. Nakamura $\mathrm{T}$ 中村利孝, 高橋力, 宮下裕芳, 増田彰男, 斉木茂 樹, 伊地知正光: 神経内 ganglionによる尺骨神経麻舫の 1 例. 整形外科 29:799-802, 1978

61. Nakamura $\mathrm{T}$ 中村巧, 原田祐次, 大久保英朋, 萩森宏: い わXXXるintraneural ganglionの2例について. 中部整災誌 27:1194-1195, 1984

62. Nakarei Y 中禮康雄, 関利明, 林㑆, 八木和徳, 荻荘則幸: 巨 大な神経内ガングリオンによる肘部管症候群の1例. 東北 整災紀要 35:436-437, 1991

63. Narabayashi Y 楢林葉子, 藤田雅章, 本川哲, 角光宏, 藤本勝 也: 神経内ガングリオンによる尺骨神経麻痷の一例. 整形 外科と災害外科 45:602-604, 1996

64. Nummi J, Solonen KA: [Intraneural ganglion of the ulnar nerve.] Handchirurgie 6:20-22, 1974 (Ger)

65. Osaka S, Ato Y, Morioka S, Sato K, Toriyama S: [Intraneural ganglion of ulnar nerve with dysplasia of the trochlea humeri: A case report.] 関東整災誌 7:36-38, 1976 (Jpn)

66. Patel MR, Naik AN, Mody K, Pollack M: Intraneural mucous cysts of peripheral nerves. Am J Orthop 26:562-564, 1997

67. Rezzouk J, Durandeau A: [Nerve compression by mucoid 
pseudocysts: arguments favoring an articular cause in 23 patients.] Rev Chir Orthop Reparatrice Appar Mot 90:143146, $2004(\mathrm{Fr})$

68. Saito H 斉藤治和, 田崎憲一, 小宮山貴継, 森本理芽子, 池田 博生: 肘部管症候群を発症した尺骨神経内ガングリオンの 1例. 日手会誌 18:249, 2001

69. Sanger J, Cortes W, Yan JG: Intraneural ganglion of the suprascapular nerve: case report. J Hand Surg [Am] 31:40-44, 2006

70. Sato M 佐藤正泰, 安藤太一郎: 神経Ganglionの3例. 日外会 誌 70(6):906, 1969

71. Schmidt HM, Lanz U: Surgical Anatomy of the Hand. Stuttgart, New York: Thieme, 2004, pp 80-81

72. Sekiguchi A 関口明, 小川清久, 都築暢之: 尺骨神経深枝に発 生した神経内ガングリオンの1例. 埼玉医大誌 8:297, 1981

73. Sharma RR, Pawar SJ, Delmendo A, Mahapatra AK: Symptomatic epineural ganglion cyst of the ulnar nerve in the cubital tunnel: a case report and brief review of the literature. J Clin Neurosci 7:542-543, 2000

74. Spinner R: Lettre à la rédaction. Rev Chir Orthop 91:492494, 2005

75. Spinner RJ, Amrami KK: Suprascapular intraneural ganglia. J Hand Surg [Am] 31:1698-1699, 2006 (Letter)

76. Spinner RJ, Amrami KK, Kliot M, Johnston SP, Casañas J: Suprascapular intraneural ganglia and glenohumeral joint connections. J Neurosurg 104:551-557, 2006

77. Spinner RJ, Amrami KK, Rock MG: The use of MR arthrography to document an occult joint communication in a recurrent peroneal intraneural ganglion. Skeletal Radiol 35:172179, 2006

78. Spinner RJ, Amrami KK, Wang H, Kliot M, Carmichael SW: Cross-over: a generalizable phenomenon necessary for secondary intraneural cyst formation. Clin Anat 21:111-118, 2008

79. Spinner RJ, Amrami KK, Wolanksyj AP, Desy NM, Wang H, Benarroch EE, et al: Dynamic phases of peroneal and tibial intraneural ganglia formation: a new dimension added to the unifying articular theory. J Neurosurg 107:296-307, 2007

80. Spinner RJ, Atkinson JL, Scheithauer BW, Rock MG, Birch R, Kim TA, et al: Peroneal intraneural ganglia: the importance of the articular branch. Clinical series. J Neurosurg 99:319329,2003

81. Spinner RJ, Atkinson JL, Tiel RL: Peroneal intraneural ganglia: the importance of the articular branch. A unifying theory. J Neurosurg 99:330-343, 2003

82. Spinner RJ, Carmichael SW, Atkinson JL: Intraneural ganglion cyst. J Neurosurg 104:990-992, 2006

83. Spinner RJ, Carmichael SW, Wang H, Parisi TJ, Skinner JA, Amrami KK: Patterns of intraneural ganglion descent. Clin Anat 10:233-245, 2008

84. Spinner RJ, Desy NM, Amrami KK: Sequential tibial and peroneal intraneural ganglia from the superior tibiofibular joint. Skeletal Radiol 37:79-84, 2008
85. Spinner RJ, Luthra G, Desy NM, Anderson ML, Amrami KK: The clock face guide to peroneal intraneural ganglia: critical "times" and sites for accurate diagnosis. Skeletal Radiol 37:1091-1099, 2008

86. Spinner RJ, Mokhtarzadeh, Schiefer TK, Krishnan KG, Kliot M, Amrami KK: The clinico-anatomic explanation for tibial intraneural ganglion cysts arising from the superior tibiofibular joint. Skeletal Radiol 36:281-292, 2007

87. Spinner RJ, Scheithauer BW, Amrami KK: Evolution-revelationrevolution: The unifying articular (synovial) origin of intraneural ganglia. Neurosurgery [in press], 2009

88. Spinner RJ, Vincent J-P, Wolanskyj AP, Scheithauer BW: Intraneural ganglion cyst: a 200-year old mystery solved. Clin Anat 21:611-618, 2008.

89. Strickland JW, Steichen JB: Nerve tumors of the hand and forearm. J Hand Surg [Am] 2:285-291, 1977

90. Takahashi M 高橋正憲, 矢部裕, 小山明, 藤中星児, 三笠 元彦: ガングリオンによる末梢神経麻痺. 中部整災誌 21:1301-1303, 1978

91. Tanaka Y, Cho R, Kanai A, Tashiro A: [Case of ulnar nerve paralysis caused by intraneural ganglion.] Seikei Geka 20:15751576, 1969 (Jpn)

92. Taze S 田制昭吾, 川上仁: Intraneural Ganglionによる尺骨神 経麻盘の1例. 日整会誌 47:629, 1973

93. Tsuruta $\mathrm{T}$ 鶴田登代志, 荻原義郎: 尺骨神経に発生したガン グリオンの1例. 日整会誌 47:720, 1973

94. Uetani M, Hashmi R, Hayashi K, Nagatani Y, Narabayashi Y, Imamura K: Peripheral nerve intraneural ganglion cyst: MR findings in three cases. J Comput Assist Tomogr 22:629-632, 1998

95. Wadstein T: Two cases of ganglia in the sheath of the peroneal nerve. Acta Orthop Scand 2:221-230, 1931

96. Wainwright AM, Burge PD: Synovial cyst of the pulp of the little finger-origin from the wrist joint. J Hand Surg [Br] 27:503506,2002

97. Wang H, Spinner RJ, Amrami KK: Radiology corner. Adventitial cyst of the radial artery and a wrist joint connection. J Hand Surg [Am] 32:126-130, 2007

98. Yasuda K 安田健一, 湯浅勝則, 松木達也, 佐藤大祐: 尺骨神 経内ガングリオンによる肘部管症候群の1例 東北整災紀 要 45:86-89, 2001

99. Zielinski CJ: Intraneural ganglion of the ulnar nerve at the wrist. Orthopedics 26:429-430, 2003

100. Zum Busch JP: Ulnarislähmung bedingt durch eine traumatische Cyste im Nervus ulnaris. Arch Klin Chir 49:451-453, 1895

Manuscript submitted October 18, 2008.

Accepted November 21, 2008.

Address correspondence to: Robert J. Spinner, M.D., Mayo Clinic, Rochester, Minnesota 55905. email: spinner.robert@mayo. edu. 